Business and Banking 
A volume in the series

\section{Cornell Studies in Political Economy}

\section{Edited by Peter J. Katzenstein}

A full list of titles in the series appears at the end of the book. 


\title{
Business and Banking
}

Political Change and Economic INTEGRation in Western EURope

\author{
Paulette Kurzer
}

Cornell University Press 
Copyright (C) 1993 by Cornell University

All rights reserved. Except for brief quotations in a review, this book, or parts thereof, must not be reproduced in any form without permission in writing from the publisher. For information, address Cornell University Press, Sage House, $5^{12}$ East State Street, Ithaca, New York 14850.

First published 1993 by Cornell University Press.

International Standard Book Number o-8014-2798-3

Library of Congress Catalog Card Number 92-56780

Printed in the United States of America

Librarians: Library of Congress cataloging information

appears on the last page of the book.

(2) The paper in this book meets the minimum requirements

of the American National Standard for Information Sciences-

Permanence of Paper for Printed Library Materials, ANSI Z39.48-1984. 